\title{
テーパ状石英棒を用いたダウンチャープ用 パルス圧縮フィル夕
}

\begin{tabular}{|c|c|c|c|c|c|}
\hline 正 員 & 吉 & 沢 & 昌 & 純 & (都立高専) \\
\hline 非会員 & 桐 & 生 & 昭 & 吾 & (電 総 研) \\
\hline E 員 & 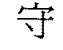 & 屋 & & & (都立大) \\
\hline 員 & & $t=$ & & & 大) \\
\hline
\end{tabular}

\section{1.まえがき}

さきに石英棒を伝般する弾性波のうち， $L(0,3)$ モ 一ドを用いて，超音波断層法用のパルス圧縮フィルタ を実現できることを報告した (1)。このフィル夕は，低 い周波数加ら高い周波数に変調された $\mathrm{FM}$ チャープ 信号（以後，アップチャープ信号と呼ぶ）を圧縮する ためのものであった。

これに対して，高い周波数から低い周波数に変調さ れた FMチャープ信号（以後，ダウンチャープ信号 と呼京）を圧縮するためのパルス圧縮フィル夕（以 後, ダウンチャープ用パルス圧縮フイル夕と呼ぶ）が あれば，(1) 単一の探触子で異なる中心周波数のアッ プチャープとダウンチャープ信号を送信し，二つの周 波数成分の異なる超音波で同時に断層像を得るマルチ スペクトル超音波断層法 ${ }^{(2)}$, また (2) 走㚗線密度とフ レーム書換レートを上げるため, 同時に二つの探触子 を用いた同時複数周波数超音波法(3)などに応用できる。 本論文は，溶融石英棒中を伝搬する弾性波のうち

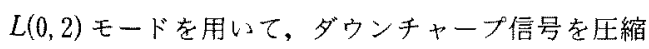
するための超音波断譄法用パルス压縮フィルタを構成 する方法について述べたものである。

これまでダウンチャープ用のフィルタは，CCDを

FM Down Chirp Pulse Compression Filter for Ultrasonotomography Utilizing $L(0,2)$ Mode of the Elastic Wave in a Fused Quartz Rod with Tapered Ends. By Masasumi Yoshizaua, Mem. ber (Tokyo Metropolitan Technical College), Shogo Kiryu, Non-member (Electrotechnical Laboratory), Tadashi Moriga, Member \& Tadashi Fuse, Member (Faculty of Technology, Tokyo Metropolitan University).

吉沢昌純：正員，東京都立工業高等曹門学校電気，工学科

桐生昭吾；非会員, 電子技術総合研究所

守犀 正: 正員, 東京都立大学工学部電気工学科

布施 正: 正買，東京都立大学王学部霆気工学科

電学論 $\mathrm{C}, 109$ 巻 8 号, 平成元年
用いたものがあっだ(4)〔しかしこのフィルタの帯域幅

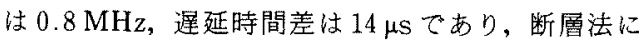
用いるには十分な特性ではなかった。

さきに報告した $L(0,3)$ モードフィルタでは，使用 する周波帯に存在する $L(0,2)$ モードにより生じる不 要信号成分を除去していた。ところが，このL $L(0,2)$ モードは， $L(0,3)$ モードと分散特性の傾きが逆であ る。このため, $L(0,3)$ モードにより生じる不要信号 成分(以後 $L(0,3)$ 不要信号成分と呼ぶ)を除去できれ

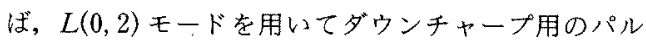
ス压縮フィル夕を構成できる。

そこで，テーバ状石英棒を用い，電荷の打消しを利 用した方法と吸収体を用いた方法を併用することによ り，不要となる $L(0,3)$ モードによる信号成分を除去 し,ダウンチャープ用パルス圧縮フィルタが実現でき ることがわかったのでその方法について述べる。

\section{2. ダウンチャープ用パルス圧縮フィルタに適} したモードの選択

まず， $L(0,2)$ モードを用いてダウンチャープ用の パルス圧縮フィル夕を構成する根拠を明らかにする。 Pochhammer-Chree の式(5)*1 加求她大直径 $1 \mathrm{~mm} の$ 溶融石英円柱棒中を伝わる弹性波の分散特性を図 1 亿 示す。図中, $\omega$ は角周波数, a は半径を表す。

Flexural, Torsional モードなどは, Longitudinal モ 一ドに比べ，振幅が十分小さかったので Longitudinal モードのみを示してある。

図 1 に扔いて, 石英棒 $1 \mathrm{~m}$ あたり $100 \mu \mathrm{s}$ 程度の漣

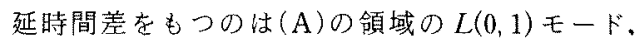
(C)の領域の $L(0,2)$ モードである。

\footnotetext{
*!:ポアソン比 0.17 , Shear Wave Velocity $=3692.57 \mathrm{~m} / \mathrm{s}$, Dilatational Wave Velocity $=5973.43 \mathrm{~m} / \mathrm{s}$ で諎した。
} 


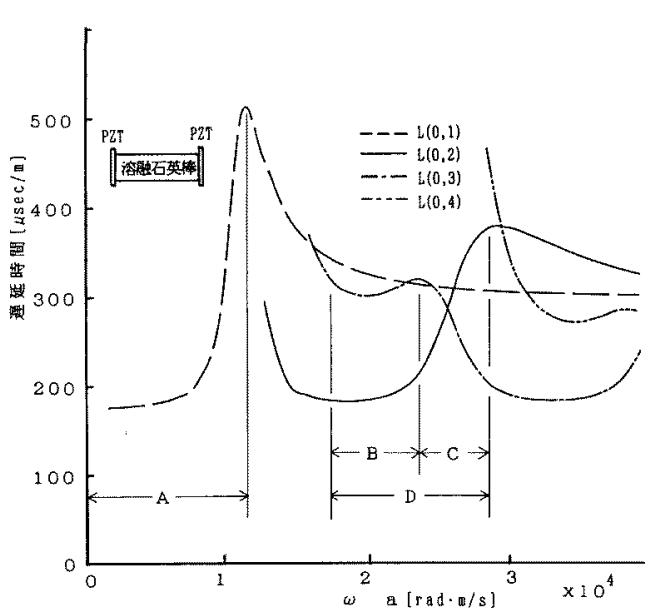

図 1 石英棒を伝わるPochhammer-Chree 波の分散特性

Fig. 1. Delay time for longitudinal modes in a fused quart $z \operatorname{rod} 1 \mathrm{~m}$ in length.

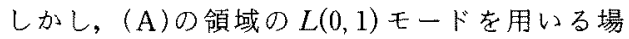
合, $1 \sim 2 \mathrm{MHz}$ 程度の帯域幅を得るためには, 直径 $0.5 \mathrm{~mm}$ 程度の石英棒を用いなければならないが，こ のような細い径の棒には効率良くPochhammerChree 波を励振することができなかった。(C)の領域 では， $L(0,2)$ モードと $L(0,3)$ モードが大きな振幅で 蚞出されており，他のモードはほとんど検出されなか $\supset t^{* 2}$ 。

そこで，このL $(0,2)$ モードを用いてダウンチャー プ用のパルス圧縮フィルタを構成することにした。

この $L(0,2)$ モードを用いた場合， $L(0,3)$ 不要信号 成分を除去する必要がある。

\section{3. $L(0,3)$ 不要信号成分の除去法}

$L(0,3)$ 不要信号成分は, $L(0,2)$ モードと $L(0,3)$ モードの断面内の振動パターンの違いを利用し, 電荷 の打消し，および吸取体を用いて除去した。

〈3・1〉振動パターンの周波数特性亦ず, $L(0$, 2) モードと $L(0,3)$ モードの石英棒断面の振動パター ンの特徵を明らかにするため, 各モードの振動パター ンを測定した。

図2の回路でサファイア針(先端径約 0.05 $\mathrm{mm}$ ）を用いた探触子を石英棒の断面内で径方向に移 動させながら測定した。図 3 は図 $10(\mathrm{D})$ の領域ての

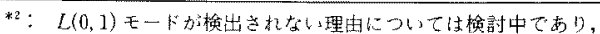

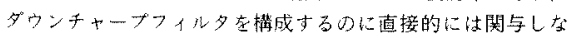

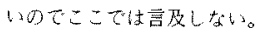

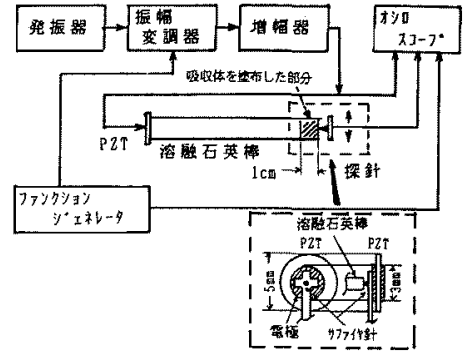

図 2 振動パターンの測定回路

Fig. 2. Arrangement for measuring vibration patterns of $L(0,1), L(0,2)$ and $L(0,3)$ modes.

$L(0,1), L(0,2), L(0,3)$ モードの各変位分布の実澌值 である。図中, Pochhammer-Chreeの式加求めた Longitudinal モードの変位の伝搬方向成分 ${ }^{(5)}$ 破線と 実線で示してある。なお，破線の部分は夷線の部分と 位相が逆であることを表しており，縦軸は振幅の最大 値で規格化してある。

必要とする带域で $L(0,3)$ 不要信号成分を除去する ためには， $L(0,2)$ モードと $L(0,3)$ モードの振動パタ ーンに特街的な違いがあり，その带域で振動パターン の変化が少ないことが必要である。図 3 から，(B)の 領域では比較的モードの変化が少なく, $L(0,2), L(0$, 3) モードの振動パターンに特徵的な違いがあること がわかる。

〈3・2〉振動パターンの違いを利用した $L(0,3)$ 不 要信号成分の除去法 図 $3 \sigma(B)$ 領域で, $L(0$,

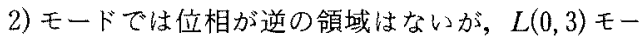
ドでは位相が逆の領域がある。そこで，電気信号と機 械振動の変換を行う $P Z T$ 上の電極面内で起こる電荷 の打消しにより， $L(0,3)$ 不要信号成分を除去できる。 まず，この電荷の打消しの大きさを表す量を導入す る。

ところで，PZT の面内の位相と振幅の分布が一様 でないと, $P Z T$ 上の電極面内で電荷の打消しが起こ り，断面内の全エネルギーに対して $P Z T$ で取出し得 るエネルギーが小さくなる。いま(平面のP P T T゙取 出し得るエネルギー）／(断面内の全エネルギー）を クで表すことにする。

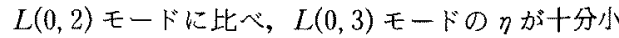
さければ $L(0,3)$ 不要信号成分を除去することができ る(6)。なお著者らが用いているフィル夕の構造で(B) の領域では，前述のように $L(0,1)$ モードは検知し之 ないほど微小なので無視する。

図 4 に各モードに対するクの周波数特性を示す。 


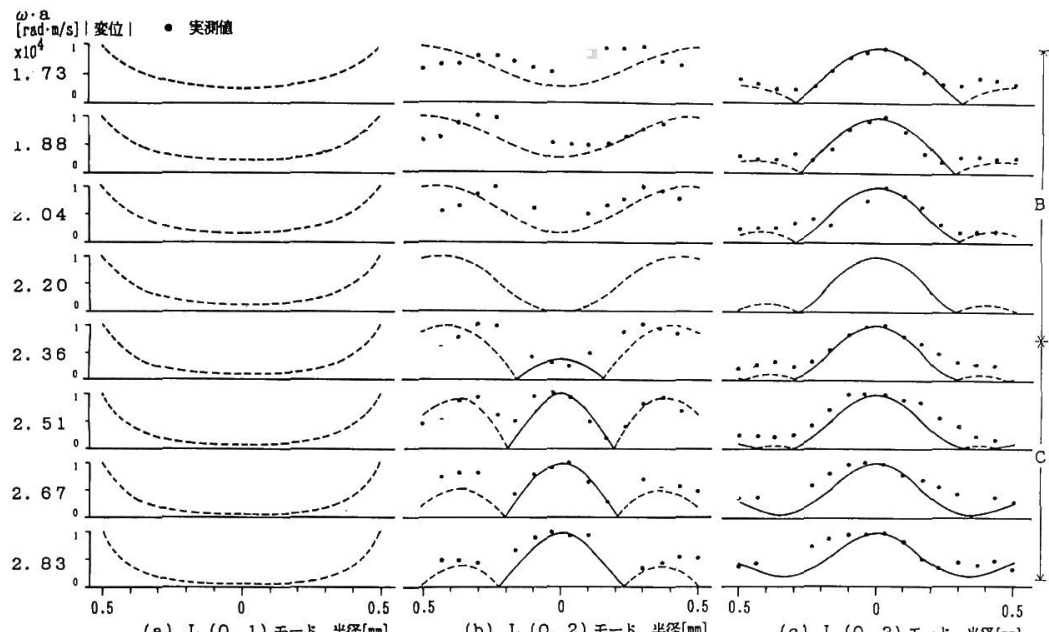

(a) L $(0,1)$ モート 半径[n]

(b) L $(0,2)$ モート 半径[nn]

(c) $\mathrm{L}(0,3) € \rightarrow k$ 米经 $[\mathrm{mm}]$

図 $3 L(0,1), L(0,2), L(0,3)$ モードの振動パターン

Fig. 3. Calculated vibration patterns of $L(0,1)$,

$L(0,2)$ and $L(0,3)$ modes.

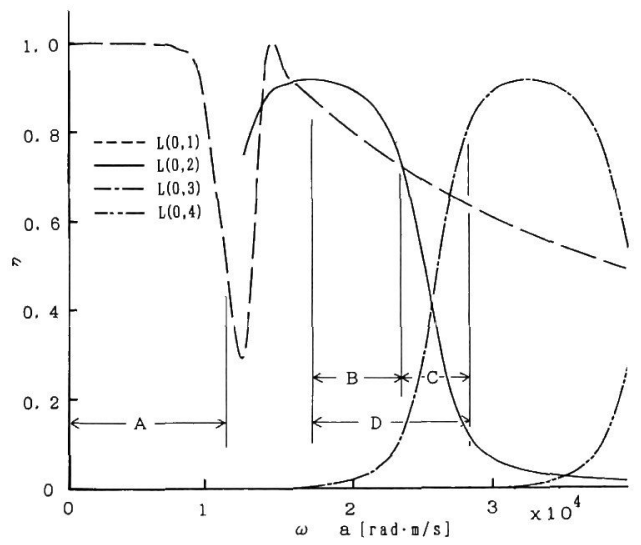

図 $4 \eta$ 対 $\omega \cdot a$ 特性

Fig. 4. $\eta$ versus $\omega \cdot a$ for each mode.

図 3, 図 4 から, (B) の領域では振動パターンの周波 数による変化が少なく，なおかつ $L(0,3)$ モードの $\eta$ が十分小さいので, 広い帯域にわたり $L(0,3)$ 不要信 号成分を除去できることがわかる。

〈3・3〉吸収体を用いた残留 $L(0,3)$ 不要信号成分 の除去法吸収体により選択的に $L(0,3)$ 不要信号 成分を除去するためには， $L(0,2)$ モードと $L(0,3)$ モ ードの伝搬形態に特徵的な違いがなければならない。 図 3 から, $L(0,2)$ と $L(0,3)$ モードの振動パターンに

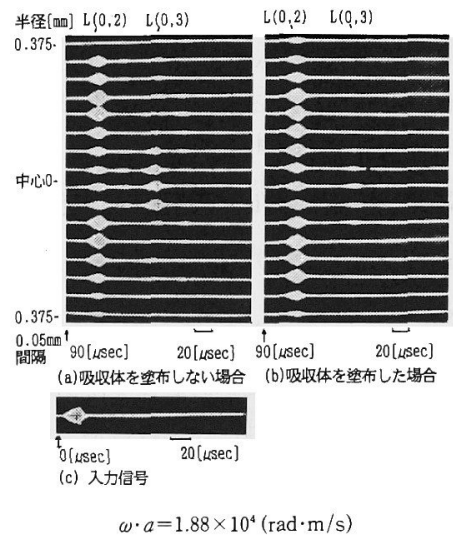

図 5 吸収体によるモードの除去

Fig. 5. Elimination of signal due to $L(0,3)$ mode using absorber.

違いがあることがわかるが, 選択的に $L(0,3)$ 不要信 号成分を除去するためには, 振動パターンと吸収体に よる信号成分の除去の関係を調べる必要がある。

図 2 の測定回路で, 図 5 (c) に示すような振幅変調 した正弦波信号を入力し，サファイア針を用いた探針 を石英棒の断面内で径方向に移動させながら写した透 過信号の写真を図 5 に示す。図 5 では $\omega \cdot a=1.88 \times$ $10^{4}(\mathrm{rad} \cdot \mathrm{m} / \mathrm{s})$ とし,（a）は何も塗布しない状態, (b)は吸収体を塗布した状態である。ここで，各モー 
ドは，遅延時間の違いによって識別した。図 5 から， 吸收体により $L(0,3)$ 不要信号成分を除去できること がわかる*3。

よって, 図 4の(B)の領域て吸収体を石英円柱棒に 㳂布すれば， $L(0,3)$ 不要信号成分を広い带域にわた り除去することができる。

\section{4. 分散性の調整}

一定径の石英円柱棒では，使用する帯域内で十分 $L(0,3)$ 不要信号成分を除去できる(B)の領域になる よう直径を選ぶと，必要とする分散性は得られない。 ところで図 1 から石英円柱棒の直径の增加に伴い (C)の領域が低い周波数に移動することがわかる。つ まり，一つのフィルタの中に変換部の直径より太い直 径の部分があれば，その部分で必要とする分散性を得 ることができる(7)。

いま, 図6に示すような両端の変換部の直径に対し て中央の直径が太くなるよう直線的に直径が変化する 構造を考える。この構造のフィル夕の分散特性を図 7 に示す。この図は, 直径が $0.1 \mathrm{~mm}$ 間隔で階段状に変 化すると近似して Pochhammer-Chree の式から求め た。図 7 加ら， $r_{2} / r_{1}$ をさくするにつれて，全体と しての分散性は小さくなるが，（B）の領域に限っては 分散性が大き々なるのがわかる。

\section{5. パルス圧縮フィルタの設計と試作}

前述の検討に基づいてパルス圧縮フィル夕を設計・ 試作した。

〈5・1〉パルス戍縮フィルタの設計 まず，図 6 に示すテーパ状石英棒の両端の直径を決める。

パルス压縮システムでは，圧縮後の信号のサイドロ ーブレベルを低減するために送信チャープ信号にアポ タイジングと呼ばれる振幅重み付けが行われる。この ため, 分散特性を示す周波数範囲は帯域幅の 2 倍程度 必要となる。いま，带域を $1 \mathrm{MHz}$ とすると分散特性 を示す周波数範囲は約 $2 \mathrm{MHz}$ 必要となる。

図6に示すフィルタで使用できる周波数範囲は, $L(0,3)$ 不要信号成分を十分除去できる(B)の領域て ある。よって，(B)の領域の周波数範囲を $2 \mathrm{MHz}$ と するため, 図 1 から，テーパ状石英棒の雨端の直径を $0.75 \mathrm{~mm}$ とする。

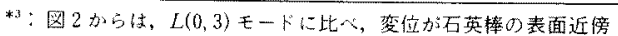

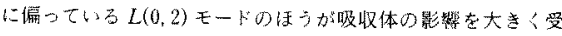

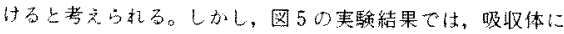

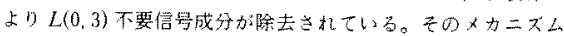

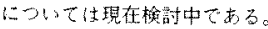

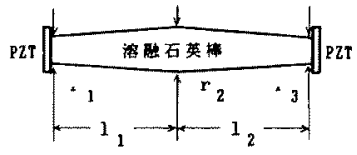

(a)バルス蟭フィル夕

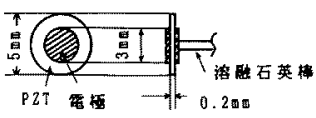

(b) $\mathrm{PZT}$

図 6 テーパ状石英棒を用いたパルス圧縮 フィルタと PZT の構造

Fig. 6. Schematic diagram of pulse compres. sion filter made of a fused quartz rod with tapered ends and $P Z T$

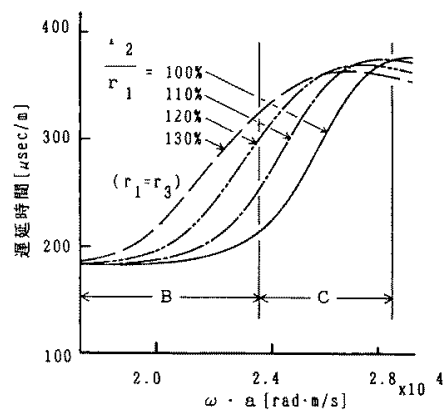

図 7 テーパ状石英棒での $L(0,2)$ モードの 分散性の計算結果

Fig. 7. Calculated delay time versus $\omega \cdot a$ for $L(0,2)$ mode in a fused quart $z$ rod with tapered ends $1 \mathrm{~m}$ in length.

次に, $2 \mathrm{MHz}$ の周波数範囲で単位長さあたり 100 $\mu \mathrm{s}$ 程度の迤延時間差を得るためテーパ状石英棒の直 径を決定する。

図 7 より，十分な $(\mathrm{B})$ の領域の分散性を得られる $r_{2} / r_{1} \fallingdotseq 130 \%$ になるようテーパ状石英棒の中央の直径 を $1 \mathrm{~mm}$ とする。必要とする遅延時間差を得るために は，テーパ状石英棒の長さを選べばよい。

〈5・2〉 パルス圧縮フィルタの試作 前述の設計 に基づき，2本のテーパ状石英棒をつないで試作した パルス圧縮フィル夕の直径分布を図 8 に示す。図 9 （a）は図 5（c）に示す振幅変調した正弦波信号を一端 のPZT に加え，周波数を $7.0 \sim 10.0 \mathrm{MHz}$ の範囲て $0.2 \mathrm{MHz}$ おきに変化させたときの透過波形である。 このとき，図 2 の測定回路で探針をPZTに付けかえ て測定した。なお， $L(0,3)$ 不要信号成分の除去の効 


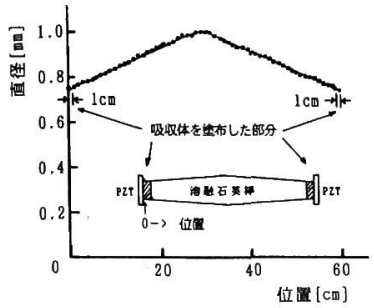

図 8 試作したテーパ状パルス压縮フィル夕 の直径分布

Fig. 8. Distribution of diameters of the fused quartz rod with tapered ends used in the experiment.

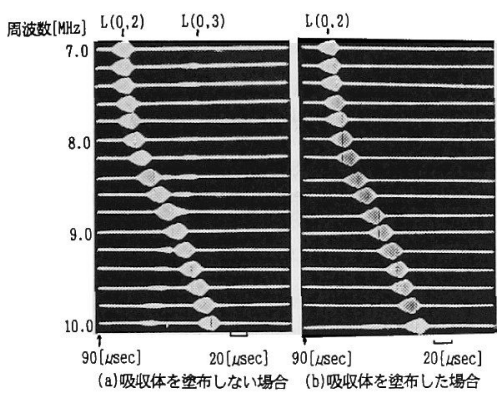

図 9 パルス压縮フィルタを透過した振幅 変調波

Fig. 9. Amplitude modulated signal through the pulse compression filter.

果を確かめるため， $L(0,2)$ モードによる信号が一定 振幅になるよう入力を調整してある。図 9 (a)のよう に,このままでは使用する帯域内の不要モードの除去 は不十分である。

そこで,〈3・3〉節で述べた吸収体を用いて $L(0,3)$ 不要信号成分の除去を行った。図 8 の斜線で示す部分 にあたる石英棒の表面に吸収体としてグリースを塗布 し，上記と同様に得た透過波形を図 9 (b)に示す。こ の図から, 吸収体により $L(0,3)$ 不要信号成分が除去 されていることがわかる。以上の結果から， $L(0,2)$ と $L(0,3)$ モードの振幅比と分散特性をプロットした のが図 10 である。図中, $V_{L(0,2),} V_{L(0,3)}$ は $L(0,2)$ モー ド $L(0,3)$ モードそれぞれによる信号成分の振幅を表 している。

なお参考のため, 図 3 と同様にして求めた $r_{1} / r_{2}=$ $133 \%$ のときの理論值を実線, および一点鎖線で示し てある。この図で 7 9.8 MHzの範囲で $L(0,3)$ 不要 信号成分は $-20 \mathrm{~dB}$ 以下に抑えられている。なお，吸

電学論C, 109 巻 8 号, 平成元年

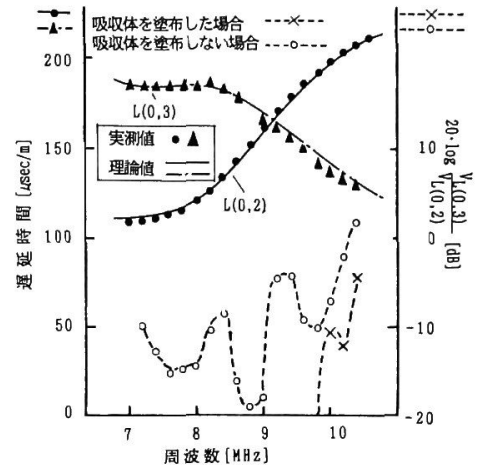

図10 テーパ状パルス压縮フィルタの分散 特性と振幅比

Fig. 10. Measured delay time and amplitude ratio for the pulse compression filter made of a fused quartz rod with tapered ends.

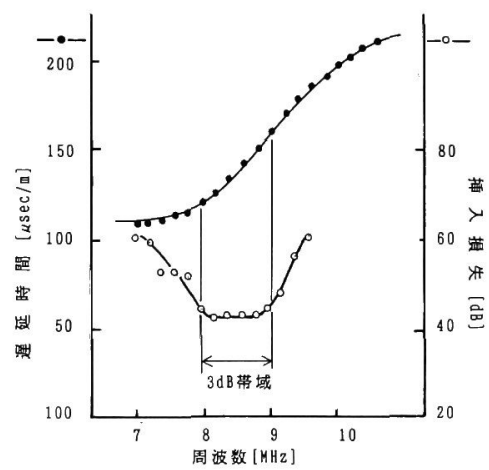

図 11 パルス圧縮フィルタの遅延時間と 插入損失の周波数特性

Fig. 11. Delay time and insertion loss of the pulse compression filter as a function of frequency.

収体を用いたときの挿入損失の増加は約 $10 \mathrm{~dB}$ であ つた。

両端の $P Z T$ の中心周波数を選ぶことにより，この フィルタの振幅特性をある程度調整できる。中心周波 数 $8.5 \mathrm{MHz}$ のPZT を使用し，捜入損失を測定した 結果を図 11 に示す。このとき, $-3 \mathrm{~dB}$ での帯域は約 $1 \mathrm{MHz}$ ，単位長さあたりの遅延時間差は約 $70 \mu \mathrm{s}$ であ った。

\section{6. まと め}

溶融石英棒中を伝搬する弾性波の $L(0,2)$ モードを 用いて, 高い周波数から低い周波数に変調された信号 
(ダウンチャープ信号) を圧縮する超音波断層法用パ ルス圧縮フィルタを構成する方法について検討した。

$L(0,2)$ モードを用いてパルス压縮フィル夕を構成 する場合，パルス圧縮後の $S / N$ 比の低下の原因とな る $L(0,3)$ モドにより生じる不要信号成分を除去す る必要がある。そこで, 石英棒断面内の各モードの振 動パターンの違いを利用し, (1) $P Z T$ 上の電極での電 荷の打消し，および，(2)吸収体，を用いて $L(0,3)$ 不 要信号成分を除去した。このとき，テーパ状溶融石英 棒を用いることにより，広い带域にわたり不要信号成 分を除去できると同時に，十分な遮延時間差を得られ ることがわかった。

更に，上記の方法を用いてダウンチャープ用パルス 圧縮フィルタを設計し, 試作したところ, 带域幅 1 $\mathrm{MHz}$, 単位長さあたりの漣延時間差約 $70 \mu \mathrm{s} の$ 結果 を得，ほほ設計ど拈り動作することを確認した。

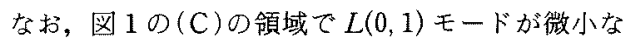
理由, および, $L(0,3)$ モードが吸取体により抑圧さ れる理由については検討中である。
終りに、本研究を行うにあたり御助言いただいた都 立大学 多気昌生助教授, 小島健二助手および実験に 御協力いただいた都立大学大学院生 松川英男氏に深 謝いたします。

(昭和63年 6 月 27 日受付, 平成元年 3 月 7 日再受付)

\section{文献}

（1）桐生，他：「溶融石英捧を伝搬する弹性波 $0 L(0,3) モ-N$

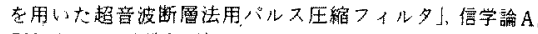
J69-A, 1006 (㖷 61-8)

(2)柯生，他：「FMチャープパス压縮技街き用いたマルチス

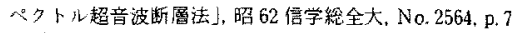

(3)志村, 他：「同時複数局波数超音波法」, 医用笔子之生体工学, 22,7 (昭 59-10)

（4）伊藤，他：「二周波弁別フィル夕」，昭56信学総全大，S81， p. 6

(5) J.E. May Jr.: "Wire-Type Dispersion Ultrasonic Delay Lines", IRE Trans. Ulirason., UE-7, 44 (1960)

(6) M. Yoshizawa, et al. "A Method for Suppressing the $L(0$. 2) Unwanted Signal in an $L(0,3)$ Mode P. C. Filter", $J$. Appl. Phys, 27, 117 (1988)

(7) Arthur H. Fitch: "Synthesis of Dispersive Delay Charac teristics by Thickness Tapering in Ultrasonic Strip Delay Lines", J. Acoust. Soc, Am, 35, 709 (1963) 